Jurnal Ekonomi dan Industri

e-ISSN: 2656-3169

Volume 21, No.3, September-Desember 2020

p- ISSN: 0853-5248

\title{
PENGARUH PELATIHAN DAN DISIPLIN KERJA TERHADAP KINERJA KARYWAN PT. JASA MARGA DI GERBANG TOL CIKAMPEK UTAMA
}

\author{
Jhon Ferry Manullang 1) \\ 1) Mahasiswa Program Studi Manajemen FE UNKRIS \\ M. Irawan Noor ${ }^{2)}$ \\ 2) Dosen Program Studi Manajemen FE UNKRIS \\ Alamat: Kampus UNKRIS, Jatiwaringin Jakarta Timur \\ Email : iwandahlia58@gmail.com
}

\begin{abstract}
To determine the effect of training and work discipline on the performance of employees of PT. Jasa Marga at the Main Cikampek Toll Gate. This research is included in the category of causal associative research using a quantitative approach. The study population was all employees of PT. Jasa Marga who served at the Main Cikampek Toll Gate. This research sampling technique using simple random sampling. This study used a sample size with the Slovin formula. Analysis method with simple and multiple linear regression. The result partially or simultaneous training and work discipline have a positive and significant effect on the performance of employees of PT. Jasa Marga Main Cikampek Toll Gate is good.
\end{abstract}

Keywords: Training, work discipline and employee performance

\section{PENDAHULUAN}

Di era digital seperti sekarang ini, kegiatan yang dilakukan oleh manusia semakin banyak dan beragam, perkembangan teknologi sekarang semua berbasis digital yang berkembang secara cepat dimana salah satunya berdampak pada sistem transaksi yang dahulunya transaksi masih menggunakan pembayaran dengan sistem tunai (cash) kemudian berkembang menjadi sistem pembayaran non tunai (non-cash) dalam bentuk $e$ money atau uang elektronik. Bank Indonesia sebagai stabilitas keuangan pada perbankan dan sistem pembayaran di Negara Indonesia mendorong agar budaya masyarakat Indonesia terbiasa memakai alat pembayaran non tunai, budaya inilah yang disebut cashless society. Dimana cashless society tentunya memiliki system mobile yang artinya sistem transaksi dapat mudah dilakukan di mana saja dan kapan saja.

Salah satu peningkatan penggunaan uang elektronik tersebut merupakan multi effect dari sistem penerapan elektronifikasi jalan tol yang dikenal dengan nama e-toll card (electronic toll card) yang mana hal ini didukung oleh keluarnya peraturan pemerintah dalam mewajibkan transaksi non-tunai di tol per 31 Oktober 2017, dan peresmian tentang aturan program 100\% wajib non tunai di jalan tol (Peraturan Menteri Pekerjaan Umum dan Perumahan Rakyat/ PUPR No. 16/PRT/M/2017) yang mana tujuan program ini adalah memberikan pelayanan dengan mengutamakan kepuasan pengguna yang berada di jalan tol agar merasakan transaksi yang lebih cepat dan efisien tanpa harus mengantre dalam waktu yang lama.

Seiring dengan perkembangan tekonologi maka dibutuhkan sumber daya manusia yang berkualitas tinggi, sumbe daya manusia adalah penentu atau pelaku yang mengendalikan serta system teknologi atau keuangan sehingga sebuah perusahaan dapat 
tetap hidup dan meningkatkan produktvitasnya. Oleh sebab itu setiap perusahaan harus mampu menjaga, memelihara dan meningkatkan kualitas sumber daya manusia yang dimilikinya.

Perusahaan yang mampu bersaing dan mampu meningkatkan produktivitasnya ditentukan oleh tersedianya sumber daya manusia yang memiliki kualitas kinerja yang profesional, mempunyai pengetahuan, kemampuan, dan disiplin kerja tinggi. Dengan memiliki sumber daya manusia yang berkualitas dan unggul akan lebih mudah bagi perusahaan untuk bersaing para kompetitornya.

Kualitas sumber daya manusia yang profesional erat berhubungan dengan kinerja karyawan dalam sebuah perusahaan. Kinerja adalah implementasi atau penerapan kemampuan seorang karyawan dalam bidang kerja yang dipercayakan kepadanya. Karena itu, di era globalisasi sekarang ini perusahaan harus memiliki karyawan atau tenaga kerja yang memiliki kualitas kinerja yang baik sehingga produktivitas perusahaan pun akan meningkat. Kenyataan ini menunjukkan bahwa sumber daya manusia memegang peranan sebagai salah satu faktor yang mempengaruhi berhasil atau tidaknya perusahaan dalam mencapai visi dan misi perusahaan. Dengan kata lain kinerja dari perusahaan sangat dipengaruhi dan tergantung pada kualitas dan kemampuan dari karyawan yang dimiliki. Karena kualitas dan kemampuan karyawan yang berkualitas akan menghasilkan kinerja karyawan yang baik pula, dan dengan kinerja karyawan yang baik, tentu kinerja perusahaan akan meningkat. Untuk mencapai kinerja karyawan yang berkualitas, diperlukan upaya yang dapat mendukung peningkatan kualitas kinerja karyawan diantara dengan mengadakan atau melakukan pelatihan, kemudian mendorong peningkatan disiplin kerja karyawan.

Untuk meningkatkan kinerja karyawan, jasa marga mengadakan program pelatihan bagi karyawannya. Pelatihan kerja merupakan keseluruhan kegiatan untuk memberi, memperoleh, meningkatkan, serta mengembangkan kompetensi kerja, produktivitas, disiplin, sikap, dan etos kerja pada tingkat keterampilan dan keahlian tertentu sesuai dengan jenjang dan kualifikasi jabatan atau pekerjaan. Pelatihan kerja merupakan salah satu jalur untuk meningkatkan kualitas serta mengembangkan karier tenaga kerja.

Faktor lain yang dapat mempengaruhi kinerja karyawan diantaranya adalah disiplin kerja, disiplin kerja sebagai suatu sikap menghormati, menghargai, patuh dan taat terhadap peraturan-peraturan yang berlaku, baik yang tertulis maupun tidak tertulis serta sanggup menjalankannya dan tidak menggelak untuk menerima sanksi-sanksinya apabila ia melanggar tugas dan wewenang yang diberikan.

PT Jasa Marga (Persero) Tbk adalah Badan Usaha Milik Negara Indonesia yang bergerak di bidang penyelenggara jasa jalan tol. Sebagai perusahaan jalan tol pertama di Indonesia, dengan pengalaman lebih dari 32 tahun dalam membangun dan mengoperasikan jalan tol, saat ini Jasa Marga adalah pemimpin dalam industry jalan tol Inonesia, dengan mengoperasikan lebih dari $576 \mathrm{~km}$ jalan tol atau $72 \%$ dari $80 \%$ lalu lintas jalan tol atau sekitar 3,4 juta kendaraan/hari melawati ruas jalan tol jasa maraga di Indonesia. Sebagai perusahaan infrastruktur penyedia jalan tol keberadaan Jasa Marga sangat dibutuhkan oleh masyarakat luas. Pertumbuhan penjualan kendaraan yang tinggi serta kebijakan otoritas pengatur jalan tol yang semakin kondusif akan membuat posisi Jasa Marga semakin kuat dalam industri jalan tol di Indonesia.

Jasa Marga akan terus berkomitmen untuk memberikan pelayanan yang senantiasa selalu ditingkatkan. Berpedoman pada Standar Pelayanan Minimum (SPM) yang ditetapkan melalui Keputusan Menteri Pekerjaan Umum Nomor 370 KPTS/M/2007 tertanggal 31 Agustus 2007. SPM tersebut memuat substansi pelayanan yang menyangkut 
aspek-aspek minimal yang harus dicapai pengelola jalan tol, yang diantaranya menyangkut kondisi jalan tol, kecepatan tempuh rata-rata, aksesibilitas, mobilitas, keselamatan, Unit Pertolongan/Penyelamatan dan Bantuan Pelayanan (www.jasamarga.com).

Perkembangan teknologi pada bidang transportasi menimbulkan berbagai kendala yang harus dihadapin dan harus segera di cari penyelesaiannya, salah satunya adalah kemacetan yang terjadi di jalan tol yang seharusnya merupakan jalan bebas hambatan dan jalan alternatif. Jalan tol Indonesia khususnya di gerbong tol Cikampek Utama, diharapkan dapat menjadi solusi yang baik karena dapat inefisiensi akibat kemacetan pada ruas utama, namun harapan tersebut tidak akan tercapai dengan baik karena kemacetan juga terjadi di jalan tol, fungsi jalan tol sebagai jalan alternatif bagi pengguna kendaraan beroda empat atau lebih untuk mempersingkat waktu tempuh dibandingkan dengan melalui jalan non-tol yang mengalami kepadatan kendaraan yang sangat parah tidak terlaksana.

Kemacetan saat ini yang terjadi di jalan tol timbul dikarenakan volume kendaraan yang terus meningkat, namun tidak dibarengi dengan pembangunan jalan yang memadai, sehingga menyebabkan ruas jalan non-tol menjadi sangat padat. Hal tersebut berimbas pada penumpukan kendaraan yang ingin menggunakan jalan tol termasuk di gerbang pintu tol karena proses pembayaran yang harus di lakukan oleh setiap kendaraan yang ingin memasuki jalan tol. Antrian kendaraan yang terlihat pada setiap gerbang atau pintu tol membuat pemerintah mencari solusi bagaimana cara jalan keluar yang terbaik dan dapat mempermudah proses transaksi pembayaran tol bagi para pengguna jalan tol.

E-toll adalah kartu prabayar contactless smartcard yang sudah bekerja sama dengan bebrapa operator jalan tol dan bank. Kartu ini dapat membantu para pengguna jalan tol untuk semakin mempermudah ketika melewati loket pembayaran tol. Membayar tol menjadi lebih mudah, praktis, karna tanpa uang receh dan uang kembalian. Sehingga transaksi di pintu loket pembayaran tol dapat lebih efektif dan efisien dalam menghemat waktu. Penggunaan e-toll hanya perlu menempelkan kartu untuk membayar uang tol dalam waktu 4 detik, lebih cepat dibandingkan bila membayar secara tunai. Penggunaan e-toll juga mengurangi biaya operasional karena hanya diperlukan biaya untuk mengumpulkan, menyetor, dan memindahkan uang tunai ke bank.

Selain menjadi langkah awal dalam modernisasi pengumpulan uang, penggunaan etoll juga dimaksudkan untuk mengurangi pelanggaran (moral hazard) karena petugas tol tidak menerima pembayaran secara langsung, dan terutama jumlah kendaraan yang semakin lama semakin menumpuk akibat sistem tunai di gerbang tol yang akan menyebabkan kemacetan dan kepadatan gerbang tol cukup sulit untuk diuraikan. E-toll juga berfungsi mengurangi adanya kesalahan-kesalahan seperti pemberian uang kembalian yang kurang, lalu adanya uang palsu, dengan meningkatnya kendaraan yang akan keluar, tentu saja penjaga tol harus dengan sigap dan cepat dalam melaksanakan tugasnya yaitu menerima uang dari pengguna tol. Jika uangnya bukanlah uang pas, tentu saja penjaga harus mengembalikannya yang terkadang memakan waktu lama.

E-toll menggunakan sistem RFID (Radio Frequency Identification) memungkinkan transaksi dapat di lakukan jarak jauh. Kartu ini di keluarkan oleh kerjasama PT. JASA MARGA Tbk, PT. Citra Marga Nusaphala Persada Tbk, Bank Mandiri Dan PT. Naga Sakti. Cara penggunaan kartu e-toll ini pada pintu masuk, kartu e-toll di tempelkan pada mesin yang telah disediakan terkait penggunaanya pada mesin pembaca, lalu pada saat pintu keluar pengguna jalan tol memberikan kartu e-toll pada petugas yang berjaga di pintu tol tersebut lalu penjaga akan mengembalikan kartu e-toll pada pengguna jalan tol beserta bukti transaksi. E-toll terdapat banyak jenis, diantaranya ada e-money yang di keluarkan oleh Bank Mandiri, Flazz yang di keluarkan oleh Bank BCA, lalu ada BRIZZI dari Bank 
BRI, dan tidak menutup kemungkinan akan semakin bertambah jenis kartu e-toll tersebut. Bagi yang sudah menjadi nasabah beberapa bank, kemudahannya lebih besar dikarenakam bisa mengisi saldo tersebut di ATM. Sedangkan jika belum menjadi nasabah bank manapun, pengguna tol bisa membeli e-toll card tersebut di beberapa minimarket yang dapat menjual saldo e-toll tersebut. E-toll tidak mempunyai expired date. Beralih menggunakan e-toll card tentu membawa dampak pada penerimaan para petugas jaga gardu tol. Atas kemunculan e-toll maka sangat berdampak terhadap tingkat kecepatan dalam melakukan transaksi pembayaran.

Fenomena yang terjadi selama ini, masyarakat pengguna jalan tol sering mengeluh mengenai kemacetan yang terjadi pada gerbang tol keluar akibat antrian para pengguna jalan tol dalam membayar tiket dengan memakai uang tunai. PT. JASA MARGA selaku badan usaha milik negara penyedia jalan tol meluncurkan inovasi Financial Technology (Fintech) di Indonesia yang merupakan sebuah inovasi berhasil mentransformasi suatu sistem atau pasar eksisting, dengan memperkenalkan kepraktisan, kemudahan akses, kenyamanan, dan biaya yang ekonomis, dikenal sebagai inovasi disruptif (Christensen dan Bower, 1995). Financial technology yang di pakai dalam hal ini berupa produk e-toll.

Tujuan penelitian ini adalah untuk mengetahui pengaruh pelatihan dan disiplin kerja terhadap kinerja karyawan PT. Jasa Marga di Gerbang Tol Cikampek Utama.

\section{LANDASAN TEORI}

\section{Pelatihan}

Pelatihan adalah sebuah proses untuk meningkatkan kompetensi karyawan dan dapat melatih kemampuan, keterampilan, keahilan dan pengetahuan karyawan guna melaksanakan pekerjaan secara efektifvitas dan efisien untuk mencapai tujuan di suatu perusahaan. Menurut Gomes (2006), pelatihan adalah "setiap usaha untuk memperbaiki performansi pekerja pada suatu pekerjaan tertentu yang sedang menjadi tanggung jawabnya, atau satu pekerjaan yang ada kaitannya dengan pekerjaannya". Menurut Widodo (2015), "pelatihan merupakan serangkaian aktivitas individu dalam meningkatkan keahlian dan pengetahuan secara sistematis sehingga mampu memiliki kinerja yang profesional di bidangnya". Pelatihan adalah proses pembelajaran yang memungkinkan pegawai melaksanakan pekerjaan yang sekarang sesuai dengan standar. Menurut Rachmawati (2008), "pelatihan merupakan wadah lingkungan bagi karyawan, di mana mereka memperoleh atau mempelajari sikap, kemampuan, keahlian, pengetahuan, dan perilaku spesifik yang berkaitan dengan pekerjaan”. Menurut Rivai dan Sagala (2013), pelatihan adalah "proses secara sistematis mengubah tingkah laku pegawai untuk mencapai tujuan organisasi". Pelatihan berkaitan dengan keahlian dan kemampuan pegawai untuk melaksanakan pekerjaan saat ini. Dari beberapa pengertian pelatihan tersebut, dapat disimpulkan bahwa pelatihan adalah sebuah proses untuk meningkatkan kompetensi karyawan dan dapat melatih kemampuan, keterampilan, keahilan dan pengetahuan karyawan guna melaksanakan pekerjaan secara efektifvitas dan efisien untuk mencapai tujuan di suatu perusahaan.

Bila suatu badan usaha menyelenggarakan pelatihan bagi karyawannya, maka perlu terlebih dahulu dijelaskan apa yang menjadi sasaran dari pada pelatihan tersebut. Dalam pelatihan tersebut ada beberapa sasaran utama yang ingin dicapai. Menurut Widodo (2015), mengemukakan bahwa "tujuan pelatihan yang dilakukan oleh perusahaan adalah untuk meningkatkan produktivitas, meningkatkan kualitas, mendukung perencanaan SDM, meningkatkan moral anggota, memberikan kompensasi yang tidak langsung, meningkatkan 
kesehatan dan keselamatan kerja, mencegah kedaluarsa kemampuan dan pengetahuan personel, meningkatkan perkembangan kemampuan dan keahlian personel". Pelatihan bertujuan untuk meningkatkan penguasaan teori dan keterampilan memutusakan terhadap persoalan-persoalan yang menyangkut kegiatan mencapai tujuan.

Menurut Rivai dan Sagala (2013), adapun manfaat pelatihan yang dibagikan menjadi tiga golongan, yaitu: 1)."Manfaat untuk karyawan; a). Membantu karyawan dalam membuat keputusan dan pemecahan masalah yang lebih efektif. b). Melalui pelatihan dan pengembangan, variabel pengenalan, pencapaian prestasi, pertumbuhan, tanggung jawab dan kemajuan dapat diinternalisasi dan dilaksanakan. c). Membatu mendorong dan mencapai pengembangan diri dan rasa percaya diri. d). Membantu karyawan mengatasi stress, tekanan, frustasi, dan konflik. 2). Manfaat untuk perusahaan; a). Mengarahkan untuk meningkatkan profitabilitas atau sikap yang lebih positif terhadap orientasi profit. b). Memperbaiki pengetahuan kerja dan keahlian pada semua level perusahaan. c). Memperbaiki sumber daya manusia. d). Membantu karyawan untuk mengetahui tujuan perusahaan. e). Membantu menciptakan image perusahaan yang lebih baik. f). Mendukung otentitas, keterbukaan dan kepercayaan. g). Meningkatkan hubungan antara atasan dan bawahan. h). Membantu pengembangan perusahaan. 3). Manfaat dalam hubungan sumber daya manusia, intra dan antar grup dan individu; a). Menigkatkan komunikasi antar group dan individual. b). Membantu dalam orientasi bagi karyawan baru dan karyawan transfer atau promosi. c). Memberikan informasi tentang kesamaan kesempatan dan aksi afirmatif. d). Memberikan informasi tentang hukum pemerintah dan kebijakan internasional. e). Meningkatkan keterampilan interpersonal. f). Membuat kebijakan perusahaan, aturan dan regulasi. g). Meningakatkan kualitas moral. h). Membangun kohesivitas dalam kelompok".

Menurut Sutrisno (2016), enan sasaran pelatihan sebagai berikut: 1). "Meningkatkan produktivitas kerja. 2). Meningkatkan mutu kerja. 3). Meningkatkan ketepatan dalam perencanaan sumber daya manusia. 4). Meningkatkan moral kerja. 5). Menjaga kesehatan dan keselamatan. 6). Menunjang pertumbuhan pribadi". Ada beberapa indikator dalam pelatihan seperti yang akan dijelaskan oleh Mangkunegara (2015), yaitu sebagai berikut: 1). "Instruktur. 2). Peserta. 3). Materi. 4). Metode. 5). Tujuan".

\section{Disiplin Kerja}

Kedisiplinan merupakan fungsi operasional manajemen sumber daya manusia yang terpenting karena semakin baik disiplin kerja pegawai, semakin baik kinerja yang dapat dicapai. Tanpa disiplin yang baik, sulit bagi organisasi untuk mencapai hasil yang optimal. Kedisiplinan merupakan faktor yang utama yang diperlukan sebagai alat peringatan terhadap pegawai yang tidak mau berubah sifat dan perilakunya. Sehingga seorang pegawai dikatakan memiliki disiplin yang baik jika pegawai tersebut memiliki rasa tanggung jawab terhadap tugas yang diberikan kepadanya. Menegakkan disiplin kerja sangat penting bagi perusahaan. Adanya disiplin kerja akan menjamin terpeliharanya tata tertib dan kelancaran pelaksanaan kerja perusahaan, sehingga memperoleh hasil yang optimal. Sedangkan bagi karyawan, disiplin kerja memberikan dampak suasana kerja yang menyenangkan sehingga akan menambah semangat dalam melaksanakan pekerjaannya.

Berikut adalah pengertian disiplin kerja menurut para ahli diantaranya, yaitu menurut Hasibuan (2017) "disiplin kerja adalah kesadaran dan kerelaan seseorang dalam menaati semua peraturan perusahaan dan norma-norma sosial yang berlaku". Menurut Rivai (2015), "disiplin kerja adalah suatu alat yang dipergunakan para manajer untuk berkomunikasi dengan karyawan agar mereka bersedia untuk mengubah suatu perilaku 
serta sebagai suatu upaya untuk meningkatkan kesadaran dan kesedian seorang dalam memenuhi segala peraturan perusahaan." Berdasarkan pengertian disiplin kerja yang dikemukakan oleh beberapa ahli dapat disimpulkan bahwa disiplin kerja adalah sikap kesadaran, kerelaan dan kesedian seseorang dalam mematuhi dan menaati peraturan dan norma-norma sosial yang berlaku di lingkungan sekitarnya.

Pelanggaran kerja adalah setiap ucapan, tulisan, perbuatan seorang pegawai yang melanggar peraturan disiplin yang telah diatur oleh pimpinan organisasi. Sanksi pelanggaran kerja adalah hukuman disiplin yang dijatuhkan oleh pimpinan organisasi kepada pegawai yang melanggar peraturan disiplin yang telah diatur pimpinan organisasi. Menurut Rivai (2015), ada beberapa tingkatan dan jenis sanksi pelanggaran kerja yang umumnya berlaku dalam suatu organisasi yaitu: 1). "Sanksi pelanggaran ringan dengan jenis seperti teguran lisan, teguran tertulis, pernyataan tidak puas secara tertulis. 2). Sanksi pelanggaran sedang dengan jenis seperti penundaan kenaikan gaji, penurunan gaji, penundaan kenaikan pangkat. 3). Sanksi pelanggaran berat dengan jenis seperti penurunan pangkat, pemecatan".

Menurut Hasibuan (2017), ada beberapat faktor yang bisa mempengaruhi tingkat disiplin kerja, diantaranya yaitu: 1). "Tujuan dan kemampuan; Tujuan dan kemampuan ikut mempengaruhi tingkat kedisiplinan karyawan. Tujuan yang akan dicapai harus jelas dan ditetapkan secara ideal juga cukup menantang bagi kemampuan karyawan. Hal ini berarti tujuan (pekerjaan) yang dibebankan kepada karyawan harus sesuai dengan kemampuan karyawan bersangkutan, agar dia bekerja sungguh-sungguh dan disiplin dalam mengerjakannya. 2). Kepemimpinan; Kepemimpinan sangat berperan dalam menentukan kedisiplinan karyawan, karena pimpinan dijadikan teladan dan panutan oleh para bawahannya. Pimpinan harus mencontohkan perilaku yang baik agar ditiru oleh bawahannya. Seorang Pemimpin jangan mengharapkan kedisiplinan bawahannya akan baik, jika dia pun tak mampu mencontohkan perilaku disiplin yang baik kepada bawahannya. 3). Balas jasa; Balas jasa berupa gaji dan kesejahteraan ikut mempengaruhi kedisiplinan karyawan karena balas jasa akan memberikan kepuasan dan kecintaan karyawan terhadap perusahaan/pekerjaannya. Apabila kecintaan karyawan semakin baik terhadap pekerjaan, kedisiplinan mereka akan semakin baik pula. 4). Keadilan; Keadilan ikut mendorong terwujudnya kedisiplinan karyawan, karena ego dan sifat manusia yang selalu merasa dirinya penting dan minta diperlakukan sama dengan manusia lainnya. Dengan keadilan yang baik akan menciptakan kedisiplinan yang baik pula. Jadi, keadilan harus diterapkan dengan baik pada setiap perusahaan supaya kedisiplinan karyawan perusahaan baik pula. 5). Waskat; Waskat (pengawasan melekat) yaitu tindakan nyata dan paling efektif dalam mewujudkan kedisiplinan karyawan perusahaan. Waskat efektif merangsang kedisiplinan dan moral kerja karyawan. Karyawan merasa mendapat perhatian, bimbingan, petunjuk, pengarahan, dan pengawasan dari atasannya. 6). Ketegasan; Ketegasan pimpinan dalam melakukan tindakan akan mempengaruhi kedisiplinan karyawan perusahaan. Pimpinan harus berani dan tegas, bertindak untuk menghukum setiap karyawan yang indisipliner sesuai dengan sanksi hukuman yang telah ditetapkan. Ketegasan pimpinan menegur dan menghukum setiap karyawan yang indisipliner akan mewujudkan kedisiplinan yang baik pada perusahaan tersebut. 7). Sanksi; Dengan sanksi hukuman yang semakin berat, karyawan akan semakin takut melanggar peraturan perusahaan, sikap, perilaku indisipliner karyawan akan berkurang".

Menurut Singodimejo dalam Sutrisno (2016) indikator kerja dari disiplin kerja adalah sebagai berikut: 1). "Taat terhadap aturan waktu; Dilihat dari jam masuk kerja, jam pulang, dan jam istirahat yang tepat waktu sesuai dengan aturan yang berlaku di 
perusahaan. 2). Taat terhadap peraturan perusahaan; Peraturan dasar tentang cara berpakaian, dan bertingkah laku dalam pekerjaan. 3). Taat terhadap aturan perilaku dalam pekerjaan; Ditunjukan dengan cara-cara melakukan pekerjaan-pekerjaan sesuai dengan jabatan, tugas, dan tanggung jawab serta cara berhubungan dengan unit kerja lain. 4). Taat terhadap peraturan lainnya diperusahaan; Aturan tentang apa yang boleh dan apa yang tidak boleh dilakukan oleh para pegawai dalam perusahaan".

\section{Kinerja Karyawan}

Menurut Simanjuntak dalam Widodo (2015), kinerja adalah "tingkatan pencapaian hasil atas pelaksanaan tugas tertentu". Simanjuntak juga mengartikan "kinerja individu sebagai tingkat pencapaian hasil kerja seseorang dari sasaran yang harus dicapai atau tugas yang harus dilaksanakan dalam kurun waktu tertentu". Menurut Mangkunegara (2015), kinerja karyawan (prestasi kerja) adalah "hasil kerja secara kualitas dan kuantitas yang dicapai oleh seseorang karyawan dalam melaksanakan tugasnya sesuai dengan tanggung jawab yang diberikan kepadanya". Menurut Dessler (2015), kinerja adalah "prestasi kerja, yaitu perbandingan antara hasil kerja yang dicapai dengan standar yang ditetapkan".

Menurut Mc Cleland (Mangkunegara, 2015), berikut ini adalah 6 karakteristik seseorang yang memiliki kinerja tinggi: 1). "Mempunyai rasa tanggung jawab yang tinggi terhadap tugas dan pekerjaannya. 2). Berani mengambil dan menanggung risiko dalam pekerjaan. 3). Memiliki tujuan yang wajar dan masuk akal (realistis) dalam bekerja. 4). Mempunyai rencana kerja yang komprehensif dan berupaya untuk mewujudkan suatu tujuan yang ingin dicapai. 5). Memanfaatkan feedback (umpan balik) yang kongkrit dalam seluruh kegiatan kerja yang dilakukannya. 6). Mencari kesempatan untuk mewujudkan rencana yang telah dibuat".

Menurut Rivai dan Sagala (2013), tujuan penilaian kinerja atau prestasi kinerja karyawan pada dasarnya meliputi : 1). "Untuk mengetahui tingkat prestasi karyawan selama ini. 2). Pemberian imbalan yang serasi, misalnya untuk pemberian kenaikan gaji berkala, gaji pokok, kenaikan gaji istimewa, insentif uang. 3). Mendorong pertanggung jawaban dari karyawan. 4). Meningkatkan motivasi kerja. 5). Meningkatkan etos kerja. 6). Memperkuat hubungan antara karyawan dengan supervisor melalui diskusi tentang kemajuan kerja mereka. 7). Sebagai alat untuk memperoleh umpan balik dari karyawan untuk memperbaiki desain pekerjaan, lingkungan kerja, dan rencana karier selanjutnya. 8). Riset seleksi sebagai kriteria keberhasilan/efektivitas. 9). Sebagai salah satu sumber informasi untuk perencanaan SDM, karier dan keputusan perencanaan seleksi. 10). Membantu menempatkan karyawan dengan pekerjaan yang sesuai untuk mencapai hasil yang baik secara menyeluruh".

Menurut Sedarmayanti (2017) manfaat penilaian kinerja adalah sebagai berikut: 1). "Meningkatkan prestasi kerja; Dengan adanya penilaian, baik pimpinan maupun karyawan memperoleh umpan balik dan mereka dapat memperbaiki pekerjaan/prestasinya. 2). Memberi kesempatan kerja yang adil; Penilaian akurat dapat menjamin karyawan memperoleh kesempatan menempati sisi pekerjaan sesuai kemampuanya. 3). Kebutuhan pelatihan dan pengembangan; Melalui penilaian kinerja, terdeteksi karyawan yang kemampuannya rendah sehingga memungkinkan adanya program pelatihan untuk meningkatkan kemampuan mereka. 4). Penyesuaian kompensasi; Melalui penilaian, pimpinan dapat mengambil keputusan dalam menentukan perbaikan pemberian kompensasi, dan sebagainya. 5). Keputusan promosi dan emosi; Hasil penelitian kinerja dapat digunakan sebagai dasar pengambilan keputusan untuk mempromosikan atau mendemonstrasikan karyawan". 
Indikator untuk mengukur kinerja karyawan secara individu ada enam (Bernadin dalam Nursasongko, 2012), yaitu: 1). "Kualitas; Kualitas kerja diukur dari persepsi karyawan terhadap kualitas pekerjaan yang dihasilkan serta kesempurnaan tugas terhadap keterampilan dan kemampuan karyawan. 2). Kuantitas; Merupakan jumlah yang dihasilkan dinyatakan dalam istilah seperti jumlah unit, jumlah siklus aktivitas yang diselesaikan. 3). Ketepatan waktu; Merupakan tingkat aktivitas diselesaikan pada awal waktu dinyatakan, dilihat dari sudut koordinasi dengan hasil output serta memaksimalkan waktu yang tersedia untuk aktivitas lain. 4). Efektivitas; Merupakan tingkat penggunaan sumber daya organisasi (tenaga, uang, teknologi, bahan baku) dimaksimalkan dengan maksud menaikkan hasil dari setiap unit dalam pengunaan sumber daya. 5). Kemandirian; Merupakan tingkat seorang karyawan yang nantinya akan dapat menjalankan fungsi kerjanya tanpa meminta bantuan, bimbingan dari orang lain atau pengawas. 6). Komitmen kerja; Merupakan suatu tingkat dimana karyawan mempunyai komitmen kerja dengan instansi dan tanggung jawab karyawan tehadap kantor".

\section{METODE PENELITIAN}

Penelitian ini termasuk dalam kategori penelitian asosiatif kausal dengan menggunakan pendekatan kuantitatif. Populasi penelitian adalah seluruh karyawan PT. Jasa Marga yang bertugas di Gerbang Tol Cikampek Utama yang berjumlah 51 orang. Teknik pengambilan sampel dalam penelitian ini menggunakan teknik sampling jenuh (sensus), semua anggota populasi dijadikan sebagai sampel. Metode analisis yang digunakan adalah analisis regresi linear sederhana dan analisis regresi linear berganda.

\section{HASIL PENELITIAN DAN PEMBAHASAN}

\section{Hasil Penelitian}

\section{Hasil Uji Validitas dan Reliabilitas}

Berdasarkan penelitian pada bab sebelumnya dan dari data yang telah diperoleh, maka untuk dapat menentukan apakah variabel pelatihan dan disiplin kerja dapat dijadikan pengukur terhadap kinerja karyawan PT. Jasa Marga di Gerbang Tol Cikampek Utama. Namun sebelumnya data diolah terlebih dahulu dan dilakukan pengujian terhadap variabel yang digunakan yaitu pelatihan, disiplin kerja dan kinerja karyawan untuk mengetahui apakah data tersebut akurat dan dapat dipercaya.

Pengujian validitas ini dilakukan untuk menguji apakah tiap butir pernyataan telah mewakili indikator yang akan diteliti, persyaratan minimum untuk dapat dikatakan valid adalah $\mathrm{r}=0,30$. (Sugiyono, 2016). Jadi, apabila korelasi antara butir-butir pernyataan dengan skor total kurang dari 0,30, maka butiran dalam instrumen tersebut dapat dikatakan tidak valid. Uji validitas dilakukan dengan melihat korelasi antara skor masing-masing butir pernyataan dengan skor total. Berdasarkan perhitungan koefisien korelasi skor tiap butir pernyataan pelatihan dari 51 responden sebanyak 10 pernyataan, disiplin kerja sebanyak 8 pernyataan dan kinerja karyawan sebanyak 10 pernyataan dengan total skor $r$ hitung lebih besar dari r-tabel.

Pengujian reliabilitas ini dilakukan untuk menguji seberapa jauh hasil pengukuran yang dapat diandalkan secara konsisten. Pada tabel-1, hasil pengujian reliabilitas berikut, diketahui bahwa semua variabel mempunyai alpha di atas 0,6 yang berarti bahwa semua variabel dalam penelitian ini dapat diandalkan. 
Tabel-1: Hasil Uji Reliabilitas Variabel

\begin{tabular}{lccc}
\hline \multicolumn{1}{c}{ Variabel } & $\begin{array}{c}\text { Cronbach } \\
\text { Alpha }\end{array}$ & $\begin{array}{c}\text { Nilai kritis } \\
(\boldsymbol{\alpha})=\mathbf{5 \%}\end{array}$ & Keterangan \\
\hline Pelatihan & 0.702 & 0.600 & Reliabel \\
Disiplin Kerja & 0.658 & 0.600 & Reliabel \\
Kinerja Karyawan & 0.643 & 0.600 & Reliabel \\
\hline
\end{tabular}

Sumber: Data primer, diolah, 2020

\section{Analisis regresi linear berganda}

Tabel-2: Pengaruh Pelatihan dan Disiplin Kerja terhadap Kinerja Karyawan

\begin{tabular}{|c|c|c|c|c|c|c|}
\hline \multirow[b]{2}{*}{ Variabel } & \multicolumn{6}{|c|}{ Parameter } \\
\hline & $\begin{array}{c}\text { Mult. } \\
\text { R }\end{array}$ & $\begin{array}{c}\mathbf{R} \\
\text { Square }\end{array}$ & Konstanta & $\begin{array}{c}\text { Koefisien } \\
\text { Regresi }\end{array}$ & Sig. & $\alpha$ \\
\hline $\begin{array}{l}\text { Pelatihan } \\
\text { Disiplin_Kerja }\end{array}$ & 0,887 & 0,787 & 3,777 & $\begin{array}{l}0,583 \\
0,446\end{array}$ & $\begin{array}{l}0,000 \\
0,000\end{array}$ & 0,05 \\
\hline
\end{tabular}

\begin{tabular}{l} 
Pengujian Signifikan \\
\hline F hitung > F tabel $=88,655>3,191$ \\
\hline Sumber: Data primer, diolah, 2020
\end{tabular}

$$
\text { Persamaan regresi } \mathrm{Y}=3,777+0,583 \mathrm{X}_{1}+0,446 \mathrm{X}_{2}
$$

Berdasarkan tabel-2, nilai F-hitung lebih besar dari F-tabel $(88,655>3,191)$, maka Ho tolak, Ha terima, artinya ada pengaruh yang signifikan pelatihan dan disiplin kerja terhadap kinerja karyawan PT. Jasa Marga di Gerbang Tol Cikampek Utama. Nilai koefisien determinasi $\left(\mathrm{R}^{2}\right)$ sebesar 0.787 , artinya pelatihan dan disiplin kerja secara bersama-sama memberikan kontribusi sebesar 78,7\% kepada kinerja karyawan PT. Jasa Marga di Gerbang Tol Cikampek Utama, sedangkan sisanya sebesar 21,3\% disumbangkan faktor lain yang tidak dibahas dalam penelitian ini.

Pelatihan dan disiplin kerja berpengaruh positif dan signifikan terhadap kinerja karyawan PT. Jasa Marga di Gerbang Tol Cikampek Utama pada tingkat nyata 99\%. Koefisien pelatihan bertanda positif sebesar 0,583 , artinya jika ada peningkatan pelatihan, maka kinerja karyawan PT. Jasa Marga di Gerbang Tol Cikampek Utama akan meningkat atau sebaliknya dengan asumsi disiplin kerja tidak berubah. Koefisien disiplin kerja bertanda positif sebesar 0,446, artinya jika ada peningkatan disiplin kerja, maka kinerja PT. Jasa Marga di Gerbang Tol Cikampek Utama akan meningkat atau sebaliknya, dengan asumsi pelatihan tidak berubah. Dengan demikian, hipotesis pertama dapat diterima.

\section{Analisis regresi linear sederhana}

\section{Tabel-3: Pengaruh Pelatihan terhadap Kinerja Karyawan}




\begin{tabular}{lcccccc}
\hline & \multicolumn{6}{c}{ Parameter } \\
\cline { 2 - 7 } \multicolumn{1}{c}{ Variabel } & $\mathbf{R}$ & $\begin{array}{c}\mathbf{R} \\
\text { Square }\end{array}$ & $\begin{array}{c}\text { Kons } \\
\text { tanta }\end{array}$ & $\begin{array}{c}\text { Koefisien } \\
\text { Regresi }\end{array}$ & Sig & $\boldsymbol{\alpha}$ \\
\hline Pelatihan & 0,847 & 0,717 & 8,687 & 0,818 & 0,000 & 0,05 \\
\hline
\end{tabular}

\begin{tabular}{l} 
Pengujian Signifikan \\
\hline $\mathrm{t}$ hitung $>\mathrm{t}$ tabel $=11,131>2,010$ \\
\hline Sumber: Data primer, diolah 2020 \\
Persamaan regresi $\mathrm{Y}=8,687+0,818 \mathrm{X}_{1}$
\end{tabular}

Berdasarkan tabel-3, nilai koefisien determinasi $\left(\mathrm{R}^{2}\right)$ sebesar 0.717 , artinya pelatihan memberikan kontribusi sebesar $71,7 \%$ kepada kinerja karyawan PT. Jasa Marga di Gerbang Tol Cikampek Utama, sedangkan sisanya sebesar 28,3\% disumbangkan faktor lain yang tidak diteliti, seperti disiplin kerja, kompensasi, kepuasan kerja, dan sebagainya. Pelatihan berpengaruh positif dan signifikan pada tingkat nyata $99 \%$ terhadap kinerja karyawan PT. Jasa Marga di Gerbang Tol Cikampek Utama. Koefisien pelatihan bertanda positif sebesar 0,818, artinya jika ada peningkatan pelatihan, maka kinerja karyawan PT. Jasa Marga di Gerbang Tol Cikampek Utama akan meningkat atau sebaliknya. Dengan demikian, hipotesis kedua dapat diterima.

Tabel-4: Pengaruh Disiplin Kerja terhadap Kinerja Karyawan

\begin{tabular}{lcccccc}
\hline & \multicolumn{7}{c}{ Pariabel } & $\mathbf{R}$ & $\begin{array}{c}\mathbf{R} \\
\text { Square }\end{array}$ & $\begin{array}{c}\text { Kons } \\
\text { tanta }\end{array}$ & $\begin{array}{c}\text { Koefisien } \\
\text { Regresi }\end{array}$ & Sig & $\boldsymbol{\alpha}$ \\
\cline { 2 - 7 } & 0,767 & 0,589 & 10,933 & 0,951 & 0,000 & 0.05 \\
\hline Disiplin_Kerja & 0,767 & & & & \\
\hline Pengujian Signifikan & & & & \\
\hline t hitung $>$ t tabel $=8,377>2,010$
\end{tabular}

Sumber: Data primer, diolah, 2020

Persamaan regresi $\mathrm{Y}=10,933+0,951 \mathrm{X}_{2}$

Berdasarkan Tabel-4, nilai koefisien determinasi $\left(\mathrm{R}^{2}\right)$ sebesar 0.589 , artinya disiplin kerja memberikan kontribusi sebesar 58,9\% kepada kinerja karyawan PT. Jasa Marga di Gerbang Tol Cikampek Utama, sedangkan sisanya sebesar $41,1 \%$ disumbangkan faktor lain yang tidak diteliti. Disiplin kerja berpengaruh positif dan signifikan pada tingkat nyata 99\% terhadap kinerja karyawan PT. Jasa Marga di Gerbang Tol Cikampek Utama. Koefisien disiplin kerja bertanda positif sebesar 0,951, artinya jika ada peningkatan disiplin kerja, maka kinerja karyawan PT. Jasa Marga di Gerbang Tol Cikampek Utama akan meningkat atau sebaliknya. Dengan demikian, hipotesis ketiga dapat diterima.

\section{Pembahasan}

\section{Pengaruh pelatihan dan disiplin kerja terhadap kinerja karyawan PT. Jasa Marga di} Gerbang Tol Cikampek Utama

Hasil penelitian ini menunjukkan bahwa pelatihan dan disiplin kerja mendorong peningkatan kinerja karyawan PT. Jasa Marga di Gerbang Tol Cikampek Utama. Hasil penelitian ini sama dengan hasil penelitian yang dilakukan oleh Sari (2018), Efendy \& Lesmana (2018), Shella, et al, (2019), dan Hasyim, et al, (2020), yang menyatakan bahwa pelatihan dan disiplin kerja dapat mendorong peningkatan kinerja karyawan. 


\section{Pengaruh Pelatihan terhadap Kinerja Karyawan PT. Jasa Marga di Gerbang Tol Cikampek Utama}

Hasil penelitian ini menunjukkan bahwa peningkatan pelatihan dapat mendorong meningkatnya kinerja karyawan. Hal ini dikarenakan bahwa intruktur memaksimalkan penyampaian materi pada peserta, mamahami materi yang hendak diberikan, peserta semangat mengikuti pelatihan, sebelumnya peserta sudah melalui proses seleksi, materi sesuai dengan tujuan dan disesuaikan dengan komponen peserta, materi tepat sasaran, metode penyampaian materi dapat diterima peserta, dan memiliki sasaran yang jelas dan tujuan pelatihan agar peserta pelatihan dapat meningkatkan ketrampilan. Hasil penelitian ini sesuai dengan penelitian yang dilakukan oleh Sari (2018) dan Efendy \& Lesmana (2018), yang menyatakan bahwa pelatihan dapat mendorong peningkatan kinerja karyawan.

\section{Pengaruh Disiplin Kerja terhadap Kinerja Karyawan PT. Jasa Marga di Gerbang Cikampek Utama}

Hasil penelitian ini menunjukkan bahwa disiplin kerja dapat mendorong peningkatan kinerja karyawan. Hal ini dikarenakan bahwa karyawan datang dan pulang tepat waktu yang sudah ditentukan sesuai aturan, bekerja dengan pakaian rapih, bertingkah laku sopan dan ramah, bekerja seusai dengan tugas yang diembannya, kemudian bertanggung jawab atas pekerjaannya, karyawan mengetahui aturan yang dibolehkan dan yang dilarang. Hasil penelitian ini sejalan dengan penelitian yang dilakukan oleh Shella, et al, (2019), dan Hasyim, et al, (2020), yang menyatakan bahwa disiplin kerja dapat mendorong peningkatan kinerja karyawan.

\section{KESIMPULAN DAN SARAN}

\section{Kesimpulan}

Berdasarkan hasil penelitian dan pembahasan, maka dapat ditarik beberapa kesimpulan sebagai berikut: 1). Pelatihan dan disiplin kerja mendorong peningkatan kinerja karyawan PT. Jasa Marga di Gerbang Tol Cikampek Utama. 2). Pelatihan mendorong peningkatan kinerja karyawan PT. Jasa Marga di Gerbang Tol Cikampek Utama. 3). Disiplin kerja mendorong peningkatan kinerja karyawan PT. Jasa Marga di Gerbang Tol Cikampek Utama.

\section{Saran}

Berdasarkan hasil penelitian, pembahasan, dan kesimpulan yang diperoleh, maka saran yang dapat diberikan sebagai berikut: 1). Terkait dengan pelatihan kerja, pimpinan PT. Jasa Marga disarankan untuk lebih sering memotivasi karyawan untuk dapat mengikuti pelatihan dengan motivasi untuk belajar hal-hal yang mendukung kinerja karyawan lebih meningkat. Perusahaan juga harus memperhatikan materi pelatihan yang disampaikan, disesuaikan dengan kebutuhan karyawan dalam melaksanakan tugasnya. Selain itu, perusahaan juga harus memperhatikan kualitas instruktur yaitu instruktur yang lebih menguasai materi yang sesuai agar para peserta pelatihan merasa puas dan pelatihan menjadi lebih menarik, juga tidak monoton. 2). Terkait dengan disiplin kerja, pimpinan dan seluruh karyawan PT. Jasa Marga disarankan untuk menjaga peraturan yang sudah ditetapkan, mempertahankan dan melaksanakan oleh semua pihak di perusahaan tanpa terkecuali, serta dikelola dalam pengawasan sebuah manajemen personalia, agar tidak 
terjadi kelengahan, sehingga kinerja karyawan dapat meningkat. 3). Penelitian selanjutnya dapat dikembangkan dengan cara menggunakan variabel lain dalam meneliti kinerja karyawan yang berkaitan dengan pegawai jalan tol PT. Jasa Marga. 4). Hasil penelitian ini diharapkan memberikan manfaat kepada stacholder PT. Jasa Marga seperti karyawan, pimpinan, dan berbagai pihak.

\section{DAFTAR PUSTAKA}

Dessler, Gary. 2015. Manajemen Sumber Daya Manusia. Jakarta. Salemba Empat.

Efendy, Asrizal Nasution dan Lesmana, Muhammad Taufik. 2018. Pengaruh Disiplin dan Pelatihan Kerja terhadap Kinerja Karyawan PT. Hermes Realty Indonesia. Conference Paper-February 2018.

Gomes, Faustino Cardoso. 2006. Manajemen Sumber Daya Manusia. Jakarta. Andi Offset. Hasibuan, Malayu SP. 2017. Manajemen Sumber Daya Mnausia. Edisi Revisi Jakarta. PT Bumi Aksara.

Hasyim, M. Ardi, Nupi., Maje, Germanus, Ignasius, Loyala., Alimah, Vina dan Priyadi, Shintya, Ayu, Putri. 2020. Pengaruh Motivasi dan Disiplin Kerja terhadap Kinerja Karyawan PT. Kahatex". Jurnal Ekonomi \& Ekonomi Syariah. Vol. 3 No. 2, Juni 2020. E_ISSN: 2599-3410; P-ISSN: 2614-3259.

Mangkunegara, A.A. Anwar, Prabu. 2015. Perencanaan dan Pengembangan Sumber Daya Manusia. Bandung. Refika Aditama.

Nursasongko, Ginanjar, Sigit.2012. Analisis Pengaruh Kepemimpinan dan Lingkungan Kerja terhadap Kinerja Pegawai (Studi Badan Kepegawaian Daerah Kabupaten Semarang. Semarang. Repository. UNDIP.edu

Rachmawati, Kusdyah Ike. 2008. Manajemen Sumber Daya Manusia. Yogyakarta. Andi.

Rivai, Veithzal dan Sagala, Ella. 2013. Manajemen Sumber Daya Manusia untuk Perusahaan. Jakarta. Rajawali Pers.

Rivai, Veithzal. 2015. Manajemen Sumber Daya Manusia Untuk Perusahaan. Edisi Ke-7. Depok: PT. Raja Grafindo.

Sari, Pratiwi Eka. 2018. Pengaruh Pelatihan dan Disiplin Kerja terhadap Kinerja Karyawan pada PT. Bank Aceh Cabang Medan. Jurnal Manajemen dan Keuangan, Vol. 7, No. 1, Mei 2018. P-ISSN: 2252-844x; E-ISSN: 2615-1316. Hal. 100-109.

Sedarmayanti. 2017. Manajemen Sumber Daya Manusia. Bandung. Refika.

Shella., Ferri., Saeky, Fitri Yani., Hidayanti dan Putri, Yovie Ernanda. 2019. Pengaruh Pelatihan dan Disiplin Kerja terhadap Kinerja Karyawan pada PT. Growth Asia. Jurnal Wahana Inovasi, Volume 8 No. 1, Jan-Juni 2019. ISSN: 2089-8592, hal. 1-9.

Sugiyono. 2016. Metode Penelitian Kuantitatif dan Kualitatif dan $R \& D$. Bandung. CV Alfabeta

Sutrisno, Edy. 2016. Manajemen Sumber Daya Manusia. Jakarta. Kencana Prenada.

Widodo. 2015. Manajemen Pengembangan Sumber Daya Manusia. Yogyakarta. Pusaka Pelajar. 